\title{
PAMÁTKOVÁ PÉČE O TORZÁLNÍ ARCHITEKTURU VE ZLÍNSKÉM KRAJI
}

\author{
RADIM VRLA
}

\begin{abstract}
Abstrakt: Na územi Zlinského kraje, ve východni části Moravy, byla v uplynulých patnácti letech provedena rada záchranných zásahů $v$ areálech ohrožených hradních zř́cenin. Iniciátorem a organizátorem těchto akcí byl přvevážně Národní památkový ústav, územní odborné pracoviště v Kroméřži. Tyto aktivity měly poměrně široký záběr svým obsahem (shromáždění archivních dokumentů a dostupných informací, analýza di̊vod ̊̊ poškození lokalit, odborná dokumentace zř́cenin, vlastní práce památkové konzervace, stabilizace př́stupových tras, instalace informačních systémů a osvětová práce) i rozsahem (celkově bylo těmito pracemi dotčeno sedm zř́cenin hradů). Přispěvek se zabývá především zvolenými metodickými přistupy a dosaženými výsledky.
\end{abstract}

Klíčová slova: Morava - hrady-památková péče - Kř́dlo - Šaumburk-Zuvačov-Starý Světlov.

\section{Heritage Care for Architectural Ruins in the Zlín Region}

Abstract: In the last fifteen years, extensive rescue research into endangered castle ruins has been conducted in the territory of the Zlin Region, eastern Moravia. The major part of the research was initiated

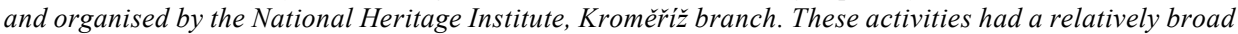
content (collection of archive documents and available information, analysis of the reasons behind the damage of the locations, specialist documentation of the ruins, heritage conservation, stabilization of access paths, installation of information systems and educational work), as well as scope (the research involved seven castle ruins). This contribution primarily focuses on the selected methodological approaches and the results they brought.

Key words: Moravia - castles - heritage care - Kř́ldlo - Šaumburk-Zuvačov - Starý Světlov.

Tento článek je součástí šiřeji koncipovaného materiálu mapujícího více aspektů dlouhodobých snah o účinnou památkovou ochranu hradních zřícenin na území dnešního Zlínského kraje, který zpracovávají kolegové Dalibor Janiš a Zdeněk Schenk. Jim i dalším zde nejmenovaným spolupracovníkům věnuji následující text.

\section{Úvod}

Jedním z neodmyslitelných prvků středoevropské krajiny jsou hradní zř́íceniny - at' už ty, co tvoří její nezaměnitelné dominanty, či ostatní, jejichž pozůstatky jsou většinou pohlceny lesem. Souhlasně s výrazem svého prostředí charakterizovaného kontrastem zániku architektury a životnosti prorůstající přírody budí ve vnímavém návštěvníkovi silné emoce. Ty téměř bezezbytku vyjádřil i nestor české kastelologie F. A. Heber:

„Zřiceniny jsou v prírodě něčím velmi ušlechtilým, jsou vzpomínkami stejně smutnými jako ony samy a načrtávají obrazy minulosti, která se nikdy nevrátí. Je to velký svátek mrtvých, lidskou řeči a lidským smutkem nevyjádřitelný. Mohou jej důstojně oslavit pouze hlasy pustiny a dunění vln oceánu!" (Heber 2002)

Obdiv k neopakovatelnému půvabu zř́icenin a snaha po jejich technickém zajištění a odvrácení jejich zániku jsou dvěma stranami téže mince. V praxi se však často vzájemně popírají. Na jedné straně stojí důstojná, emotivně působící ruina v romantickém př́írodním prostředí, jejíž technický stav však hrozí brzkým zánikem, na druhé pak stabilizovaná, ale předimenzovaným stavebním zásahem změněná, studená mrtvá hmota násilně geometrizovaných zdí. Na základě řady zkušeností, díky nimž je možno prakticky ověřit mnohé dříve vyslovené teze, je možno konstatovat, že cesta účinné památkové péče o torzální architekturu by měla být vedena vždy blíže k prvnímu pólu se snahou po uchování působivého výrazu a prostředí zříceniny, při jejím nejnutnějším a citlivém zajištění (srov. např. Kolektiv 1998; Kolektív 2006). 
Na území Zlínského kraje nalezneme poměrně velké množství zřícenin hradů či tvrzí (konkrétně 34 hradů či jejich zřícenin). Prvořadé pozornosti se již od počátku zájmu o zrríceniny dostávalo především monumentálním objektům „velkých“ zřícenin, jako jsou Cimburk u Koryčan, Lukov (obr. 1) či Brumov. Velmi vzácně jsou zde v období do první poloviny 20. století doloženy snahy o poznání a záchranu objektů, u kterých se dochovalo poměrně málo nadzemního zdiva (hrad Křídlo; Vrla 2006, 95, 96, obr. 4). Tyto objekty stojí doposud často na okraji zájmu odborné i laické veřejnosti. Přitom právě zde můžeme nalézt mimořádně hodnotné doklady středověkých stavebních a výtvarných prací a zároveň právě zde dochází často k téměř průběžným a nenávratným ztrátám bez možnosti jakékoliv dokumentace. Tyto skutečnosti vedly Národní památkový ústav, územní odborné pracoviště v Kroměříži (dále jen NPÚ), k dlouhodobému zájmu o tento druh památek (srov. např. Vrla 2008; Vrla-Sluštíková 2010-2011). Výsledky této aktivity, mající širší metodický význam, jsou shrnuty v následujícím textu. V první části bude proveden výčet dotčených lokalit se stručnou charakteristikou jejich ohrožení a způsobu nápravy, následuje závěr s pokusem o vyhodnocení celé akce.

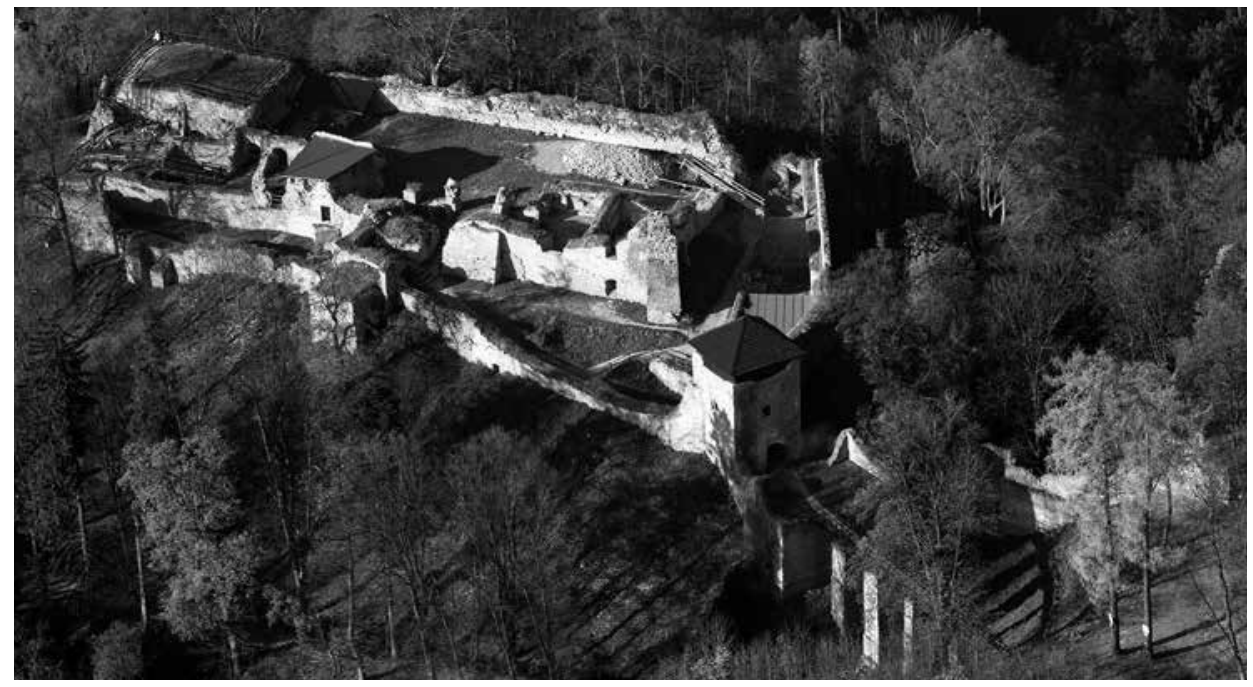

Obr. 1. Hrad Lukov, k. ú. Lukov, okr. Zlín. Letecký pohled na areál hradního jádra od jihovýchodu; jde o nejvýznamnější objekt ve Zlínském kraji, na kterém probíhají průzkumné a záchranné práce dlouhodobě. Konzervační a sanační práce zde postupují pozvolným tempem a jejich výsledky jsou velmi cenným metodickým přínosem, na který už bylo v minulosti poukázáno (Vrla 2004 , aktuální zhodnocení se zpracovává). Foto P. Baklík, 2011, archiv Spolku přátel hradu Lukova.

Abb. 1. Burg Luckow, Katastergebiet Lukov, Bezirk Zlín. Luftaufnahme auf das Gelände der Kernburg von Südosten; es handelt sich um das bedeutendste Objekt im Landkreis Zlín, an welchem langfristig angelegte Untersuchungen und Rettungsarbeiten erfolgen. Die Konservierungs- und Sanierungsarbeiten erfolgen dort in einem langsamen Tempo, und ihre Ergebnisse sind ein sehr wertvoller methodischer Beitrag, auf den in der Vergangenheit bereits hingewiesen wurde (Vrla 2004, eine aktuelle Auswertung wird z.Zt. ausgearbeitet). Foto P. Baklík, 2011, Archiv des Vereins Freunde der Burg Luckow.

\section{Jednotlivé lokality}

Hradištěk (k. ú. Újezd u Valašských Klobouk, okr. Zlín)

Na ostrožně nad centrem obce, která se jako trhová ves vzpomíná již v roce 1261 (srov. Plaček 2001, 658, 659), v blízkosti farního kostela sv. Mikuláše, jsou dochovány terénní relikty opevněného feudálního sídla (obr. 2). Pozůstávají s dnes již neúplného prstence valu a př́ikopu obklopujících výrazný terénní útvar akropole, bez viditelných pozůstatků zděných konstrukcí. K sídlu se nevztahují žádné písemné prameny, jeho název Hradištěk je novodobý.

Ještě do poloviny 20. století byl areál zčásti využíván jako ovocný sad a pastvina, což umožňovalo udržení nízkého travního porostu a památka byla dlouhodobě uchovávána v důstoj- 
ném prostř̌edí. Později však sad zpustl a prŕíkopy začaly být zaváženy odpadem z přilehlého hřbitova. Dochovaná terénní modelace zříceniny tak byla téměř zničena, areál byl postupně pohlcen divokou skládkou a houštím náletových dřevin. Archeologické situace zde sice byly zachovány, nicméně terénní modelace zrríceniny, svědčící o původním rozsahu i rámcové podobě Hradišt'ku, téměř zanikla. Ta je samozřejmě významnou součástí památkové hodnoty areálu.

V roce 1999 byly po dohodě se starostou obce podniknuty kroky k nápravě. Došlo k odstranění neproniknutelného houští, následně pak i k vyvezení skládky vyplňující příkop. Terénní modelace byla navrácena do stavu před zpustnutím a areál je dodnes pečlivě udržován v důstojném stavu a památka se opět vrátila i do povědomí místních obyvatel. Právě jejich nedostatečné povědomí o hodnotě této památky vedlo k jejímu ohrožení a poškození.

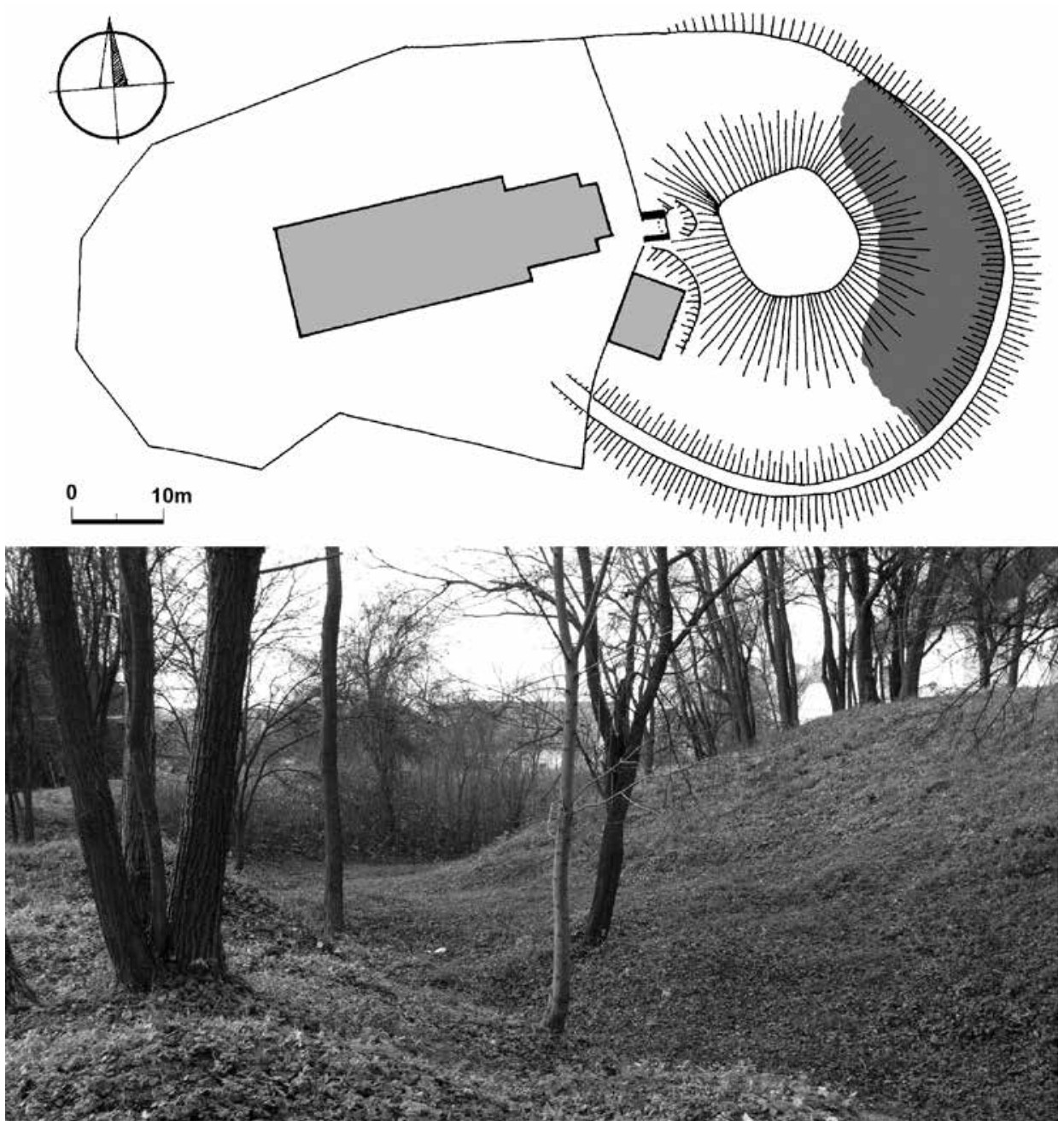

Obr. 2. Hradištěk, k. ú. Újezd u Valašských Klobouk, okr. Zlín. Nahoře půdorys areálu lokality, světle šedá plocha označuje stavbu farního kostela sv. Mikuláše (vlevo) obklopeného bývalým hřbitovem a novodobou provozní stavbou. Napravo je areál zř́ceniny panského sídla, tmavě šedá plocha označuje rozsah někdejšího smetiště. Dole východní část příkopu po vyčištění od skládky, pohled od severu (Vrla 2008).

Abb. 2. Hradištěk, Katastergebiet Újezd bei Valašské Klobouky, Bezirk Zlín. Oben der Grundriss des Fundstellenareals, die hellgraue Fläche kennzeichnet das Gebäude der Pfarrkirche St. Nikolaus (links), die von einem ehemaligen Friedhof und einem neuzeitlichen Betriebsgebäude umgeben ist. Rechts befindet sich das Areal mit den Ruinen des Burgsitzes, die dunkelgraue Fläche kennzeichnet den Umfang einer ehemaligen Müllkippe. Unten der Ostteil des Grabens nach Beseitigung der Müllkippe, Blick von Norden (Vrla 2008). 

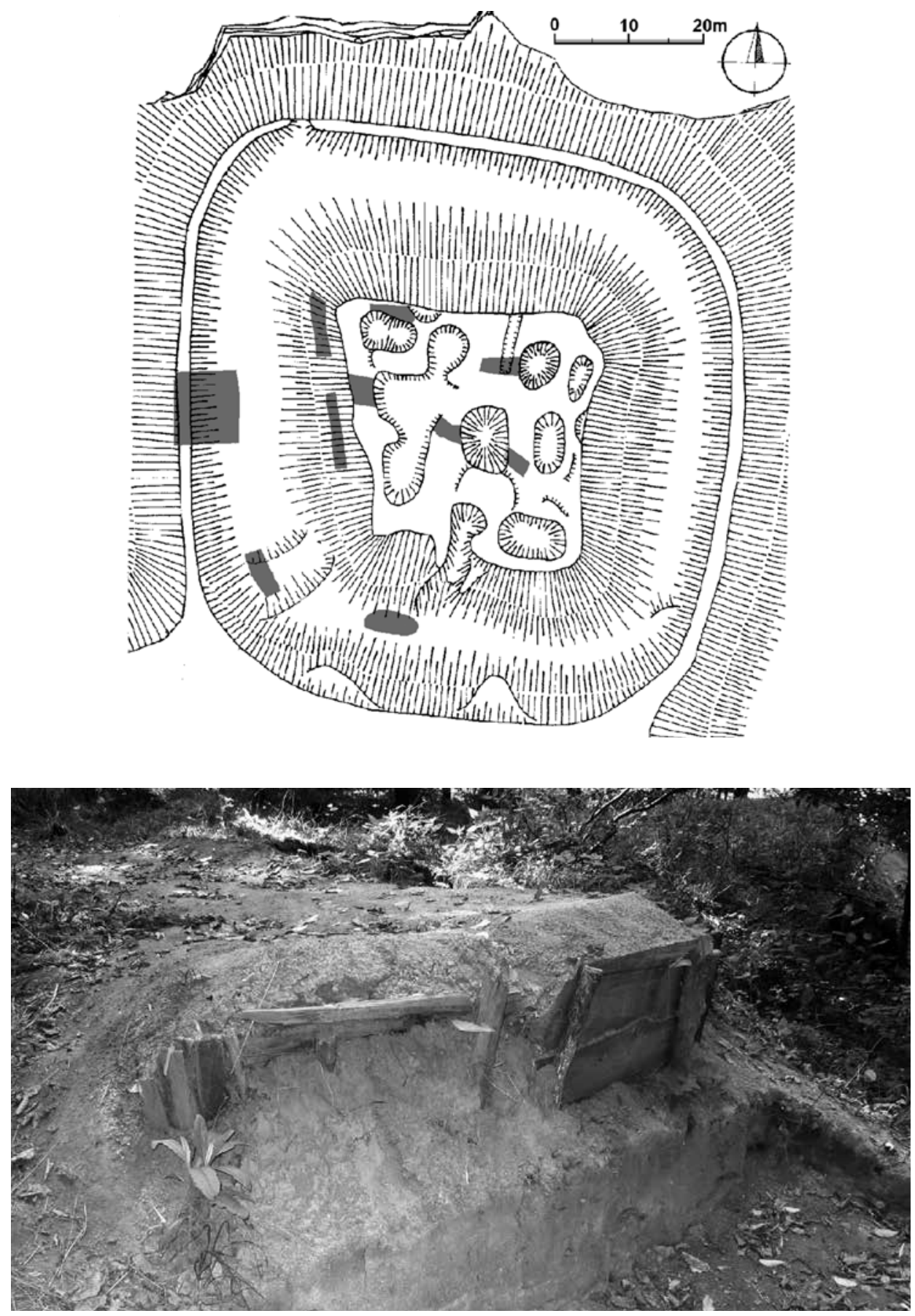

Obr. 3. Hrádek, k. ú. Žeranovice, okr. Kroměřǐž. Nahoře půdorys zř́íceniny, šedou barvou jsou vyznačeny vandalsky poškozené plochy v r. 2005. Dole snímek poškození zř́íceniny v severní části jádra (Vrla 2005).

Abb. 3. Hrádek, Katastergebiet Žeranovice, Bezirk Kroměříž. Oben Grundriss der Ruine, mit grauer Farbe wurden die im Jahr 2005 durch Vandalismus beschädigten Flächen gekennzeichnet. Unten eine Aufnahme der beschädigten Ruine im nördlichen Teil des Kernareals (Vrla 2005). 
Hrádek (k. ú. Žeranovice, okr. Kroměříž)

Hrádek je situován v poměrně odlehlé poloze na hraně mělkého údolí vykrojeného potokem Židelná v okolní mírně zvlněné krajině nedaleko obce Žeranovice. Jde o zř́íceniny panského sídla, již koncem 13. století obývaného vladyky ze Žeranovic, opuštěného v období kolem poloviny 15 . století. Zřriceniny Hrádku jsou rovněž dochovány ve formě terénních útvarů - velmi výrazné a poměrně velké jádro je obklopeno okružním př́íkopem a valem (srov. Kohoutek 1995a, 34; Plaček 2001, 735, 736).

Zříceniny, ukryté ve vzrostlém lesíku mezi okolními poli, byly v minulosti zčásti poškozeny těžbou písku, ve druhé polovině 20 . století pak byla lokalita ohrožena rozšiřující se, ale dnes již naštěstí nefunkční skládkou. V roce 2005 byly odlehlé zříceniny poškozeny poměrně rozsáhlými vandalskými terénními zásahy při budování nelegální terénní cyklotrasy (obr. 3). Došlo k poškození cenných archeologických vrstev i modelace terénu, navíc byl areál znečištěn množstvím odpadků.

K nápravě škod zde opět přispěla pomoc vlastníka - obce Žeranovic. Po odborné dokumentaci a zajištění archeologických nálezů (J. Janál, NPÚ) byly z areálu vyklizeny odpadky a poté byly četné výkopy zasypány materiálem z výsypek a modelace terénu byla upravena do podoby před vandalským poškozením. Zmíněná modelace terénu (byt’s poškozenými archeologickými vrstvami) zůstává významnou součástí památkové hodnoty Hrádku.

Hrádek u Žeranovic je poměrně odlehlou a neznámou lokalitou. Chybí označení, její existence není uváděna ani ve většině turistických map. Jak je vidět, v tomto př́padě se odlehlost a nízké povědomí o existenci zříceniny projevily spíše negativně.

Kř́ídlo (k. ú. Brusné, okr. Kroměříž)

Zřícenina pozoruhodného hradu Křídlo je situována na klesajícím severním svahu hory Barvínek, ze kterého vyrůstá výrazná skalnatá kupa. Hrad byl založen někdy v první polovině 14. století, na přelomu téhož a následného věku byl výrazně přestavěn a rozšířen a zanikl násilnou cestou ve druhé půli 15 . století. Kromě mohutných terénních útvarů jsou zde zachovány trosky zdiv. Na předhradí jsou to zbytky vstupní věže (s pozůstatky portálu brány), dalších dvou věží a hradeb, další nesouvislé zbytky zdiv jsou dochovány v obtížně přístupném hradním jádru (obr. 4/A).

Z kusých informací vyplývá, že před polovinou 20. století na hradě proběhly dílčí výkopy (brána a kruhová věž na předhradí), vyčištění a jednoduchá konzervace reliktů vstupní věže (viz výše). Postupem času se odkryté pozůstatky věže větším dílem rozpadly, část architektonických článků byla rozkradena. Katastrofální následky měla vichřice v roce 2002, která zde zničila část lesního porostu i další zbytky zdiva hradu. Na počátku roku 2005 se tak podstatná část zrrícenin hradu Kř́ídlo ocitla na prahu fyzického konce své existence.

Ve zmíněném roce 2005 došlo $\mathrm{k}$ dohodě mezi soukromým majitelem hradu a NPÚ na vypracování zadání záchrany ohrožené zř́íceniny hradu Kř́ído a po nezbytných povoleních se následně rozběhly i vlastní záchranné práce. Toto zadání (Vrla 2005) především vymezilo předmět zásahu; tím měly být zejména průzkum a konzervace nedávno poškozené a ohrožené partie zdiva hradu. Dále zde byl stanoven postup prací; po shromáždění dostupné historické dokumentace bude provedeno vyčištění poškozených konstrukcí a jejich zaměření. Poté budou koruny původního zdiva opatřeny ochrannou nadezdívkou, pro jejíž provedení jsou stanoveny následující podmínky: Líce nadezdívky budou mírně zasunuty za líce původního zdiva, svým výrazem (tedy skladbou kamene, barvou a strukturou malty, šíŕkou spár apod.) budou odpovídat lícům původního zdiva. Koruna nadezdívky nebude geometrizována, bude provedena $\mathrm{v}$ přirozené nerovnosti. Koruny nadezdívek budou ve finální podobě zadrnovány.

Vyčištění zdiva, jeho odborná dokumentace a následně i konzervační práce byly prováděny v rámci pracovních setkání (workshopů), pořádaných zpočátku Zlínským krajem (dále jen: ZK) a NPÚ. Později tyto akce, probíhající v podstatě dodnes, organizoval pouze NPÚ (Vrla 2011). 
Kromě pracovníků památkové péče (z řad NPÚ, ZK i pověřených obcí) se zapojili do prací i členové občanských sdružení (např. Klub Augusta Sedláčka, Spolek přátel hradu Lukova, občanské sdružení Polypeje a další) či amatérští nadšenci. Díky vstřícnosti soukromého majitele hradu zde v letech 2005-2007 mohlo dojít ke konzervaci torz zmíněné dvojice věží, která patřila k nejohroženějším částem areálu (obr. 5; Hrčka-Kohút-Makýš 2006, 171; Vrla-Hodaňová 2008, 74-76). Na ty to práce navázalo později vybudování jednoduchého terénního schodiště, bezpečně zpřístupňujícího hradní jádro (obr. 4/B) a další, drobnější práce, včetně odstraňování náletových dřevin ze zdiva.

Hrad Křídlo se pro nás stal jakýmsi ověřovacím místem pro praktický př́istup $\mathrm{k}$ ochraně památek tohoto druhu. Nešlo jenom o ověření technologie či pracovních postupů, ale i o nalezení nezbytné míry zásahu a ověření jeho životnosti. Zároveň šlo o prověření zájmu veřejnosti a „usazení " památky a její ochrany v povědomí místních obyvatel. Máme za to, že se nám v tomto př́ípadě podařilo provést sérii potřebných a kultivovaných zásahů, které umožnily účinnou ochranu zanikajících částí hradu a přitom nijak negativně neovlivnily důstojné prostředí památky, charakterizované zbytky architektury v nerušeném lesním prostředí.
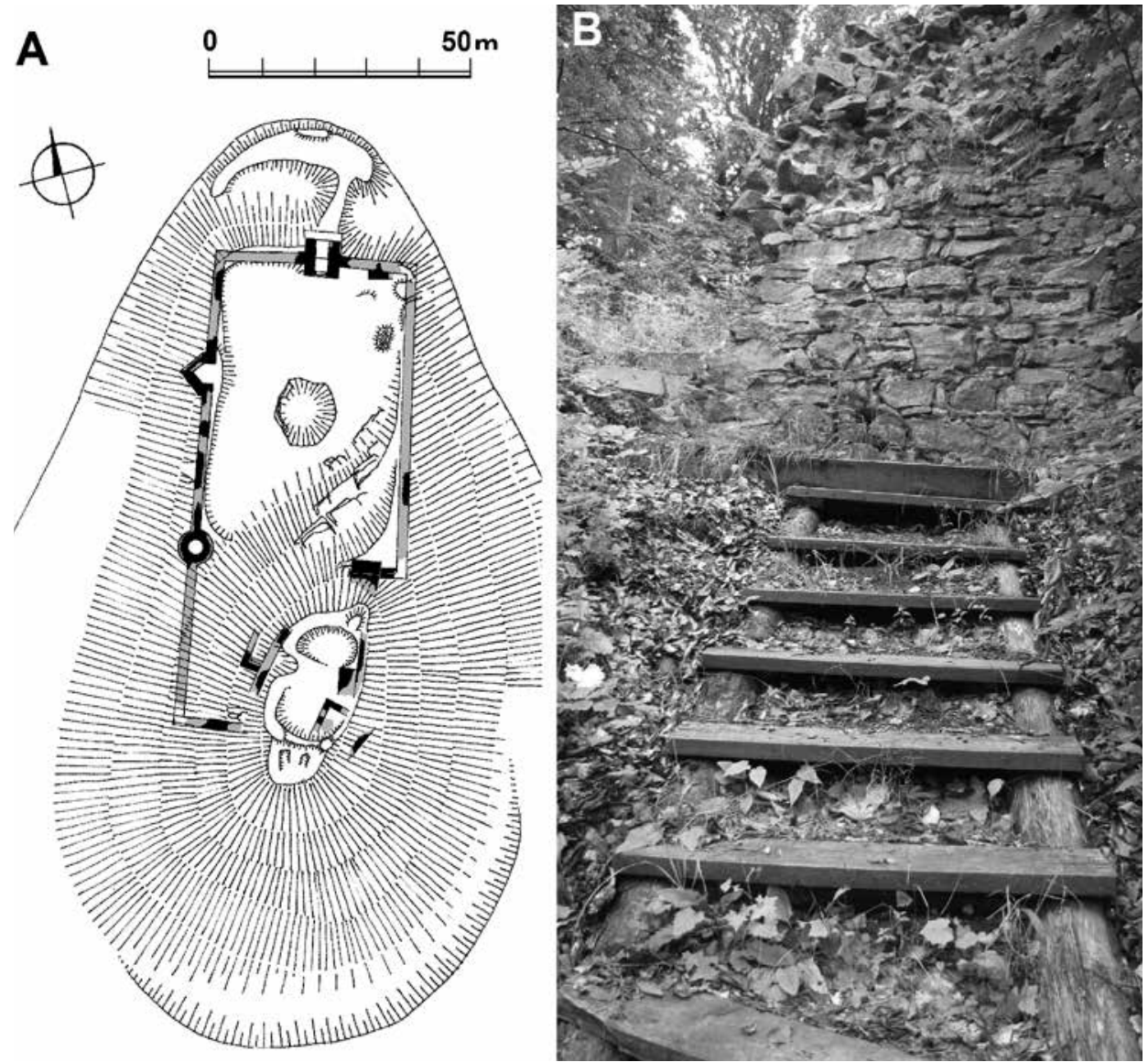

Obr. 4. Kř́ídlo, k. ú. Brusné, okr. Kroměříž. A - půdorys zř́íceniny, černě - zdivo vystupující nad terén, šedě - zjištěné či předpokládané zdivo, dochované pod terénem. Nahoře areál předhradí se vstupní věží na severní straně a dalšími věžemi v západní hradbě. Dole zříceniny hradního jádra. B - dřevěné terénní schodiště, instalované v roce 2010 na severním svahu jádra (Vrla 2014).

Abb. 4. Kř́ídlo, Katastergebiet Brusné, Bezirk Kroměříž. A - Grundriss der Ruine, schwarz - aus dem Gelände hervortretendes Mauerwerk, grau - unter der Geländeoberfläche erhalten gebliebenes, entdecktes bzw. vorausgesetztes Mauerwerk. Oben das Areal der Vorburg mit Eingangsturm an der Nordseite und mit weiteren Türmen in der westlichen Wehrmauer. Unten die Ruinen der Kernburg. B - im Jahr 2010 am Nordhang des Kernareals angelegte hölzerne Geländetreppe (Vrla 2014). 

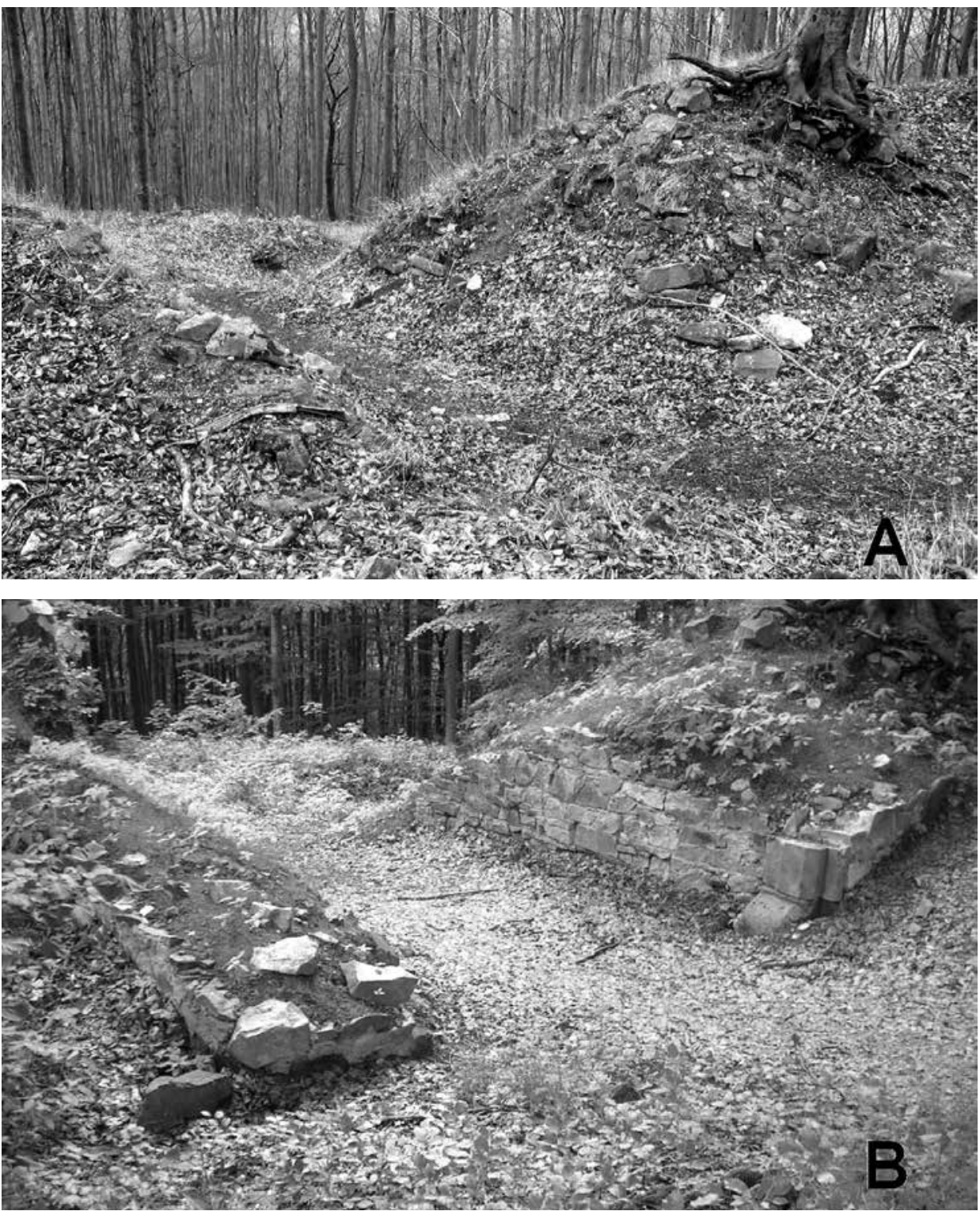

Obr. 5. Kř́ídlo, k. ú. Brusné, okr. Kroměříž. A - zříceniny vstupní, hranolové věže od jihozápadu, stav v roce 2005 po dlouhodobé postupné destrukci. B - tatáž partie po konzervaci (Vrla 2006).

Abb. 5. Kř́́dlo, Katastergebiet Brusné, Bezirk Kroměřǐ̌. A - Ruinen des Prismenturms am Eingang von Südwesten, Zustand im Jahr 2005 nach langanhaltendem Zerfallsprozess. B - dieselbe Partie nach der Konservierung (Vrla 2006).

Šaumburk (k. ú. Rajnochovice, okr. Kroměříž)

Zříceniny hradu Šaumburku jsou situovány na temeni výrazné ostrožny vybíhající severně z kóty Černá Bařina v Hostýnských vrších $(608 \mathrm{~m}$ n.m.). Hrad založil ve druhé polovině 13. století olomoucký biskup Bruno ze Šaumburka a již počátkem století následujícího byl opuštěn. Komplex sestávající z mohutných terénních útvarů a pozůstatků kamenné architektury dodnes budí úctu svými rozměry, které jej řadí mezi nejrozsáhlejší hradní stavby 13. století na úze- 

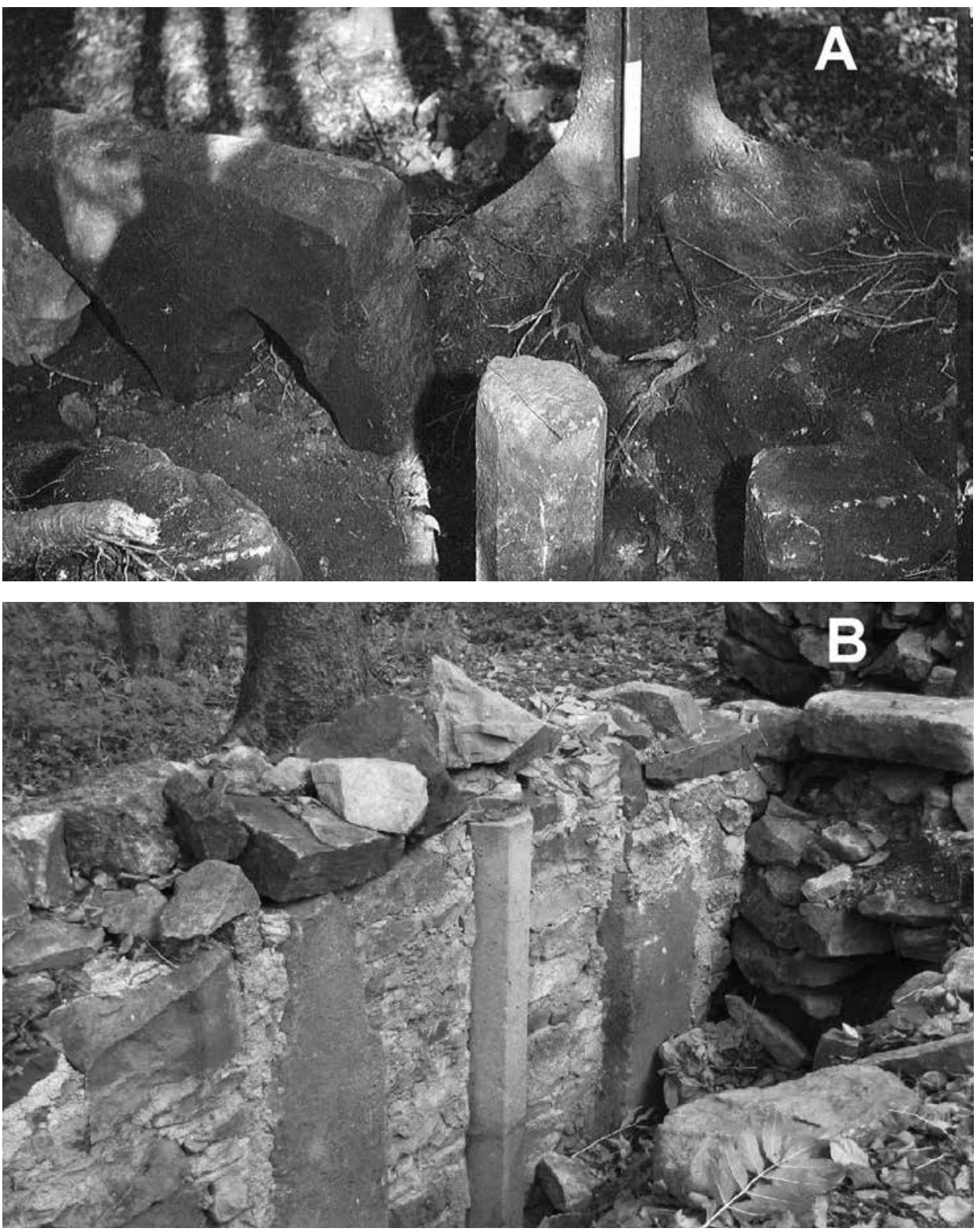

Obr. 6. Šaumburk, k. ú. Rajnochovice, okr. Kroměříž. A - fotografie situace kolem odkrytého torza raně gotického okna v severním paláci hradu, pohled od jihu (Kohoutek, 80. léta 20. století). B - tatáž partie po konzervaci a vložení ochranné zazdívky, pohled od jihozápadu (Vrla 2009).

Abb. 6. Schaumburg, Katastergebiet Rajnochovice, Bezirk Kroměříž. A - Foto der Situation um den freigelegten Torso eines frühgotischen Fensters im nördlichen Palas der Burg, Blick von Süden (Kohoutek, achtziger Jahre 20. Jhdt.). B - dieselbe Partie nach der Konservierung und nach Anbringung einer Schutzvermauerung, Blick von Südwesten (Vrla 2009).

mí českého státu. O hodnotě lokality svědčí i několik poměrně dobře dochovaných architektonických detailů z jeho původní kvalitní výbavy (Kohoutek 1995, 97-103; Plaček 2001, 603-605).

Mezi ně patří i ostění sdruženého gotického okna nalezené při archeologickém výzkumu, prováděném J. Kohoutkem v 80 . letech 20. století (obr. 6/A). Jeho stojky i parapet byly doposud vetknuty do zdiva, střední sloupek i archivolta byly uvolněny. Po ukončení výzkumu, v jehož 
rámci byly pozůstatky okna opět zasypány, došlo několikrát k jejich opětovnému amatérskému obnažení, následně byla celá situace vandaly téměř zničena a část prvků (střední sloupek a archivolta) byla odcizena. V takovémto stavu byla situace dokumentována v roce 2007.

V témže roce navázal NPÚ spolupráci s nedalekými obcemi Rajnochovice a Podhradní Lhota a vypracoval zadání chystaného záchranného zásahu na Šaumburku (Janál-Štětina-Vrla 2006). Úkolem bylo zachránit a účinně ochránit cenné architektonické detaily včetně dochované nálezové situace. Šlo hlavně o raně gotické sdružené okno (viz výše) s pozůstatky dřevěných obkladů parapetu a otisků po zasouvacích závorách (obr. 7; srov. Štětina-Vrla 2008). Opětovné zasypání v tomto prrípadě nebylo účinné, a proto bylo zvoleno jiné řešení. To spočívalo ve vyčištění a dokumentaci celé situace, následném opětovném osazení uvolněných stojek a konzervaci přilehlého narušeného zdiva. Poté byla vnější část hluboké okenní niky opatřena poměrně subtilní kamennou zazdívkou, chránící ohroženou část vyústění niky se zbytky ostění. Zazdívka byla vložena na separační vrstvu geotextilie a její líc byl zasunut za fasádu okolního zdiva. V rámci prací byla vyrobena kopie odcizeného dělicího sloupku a osazena do líce novodobé zazdívky

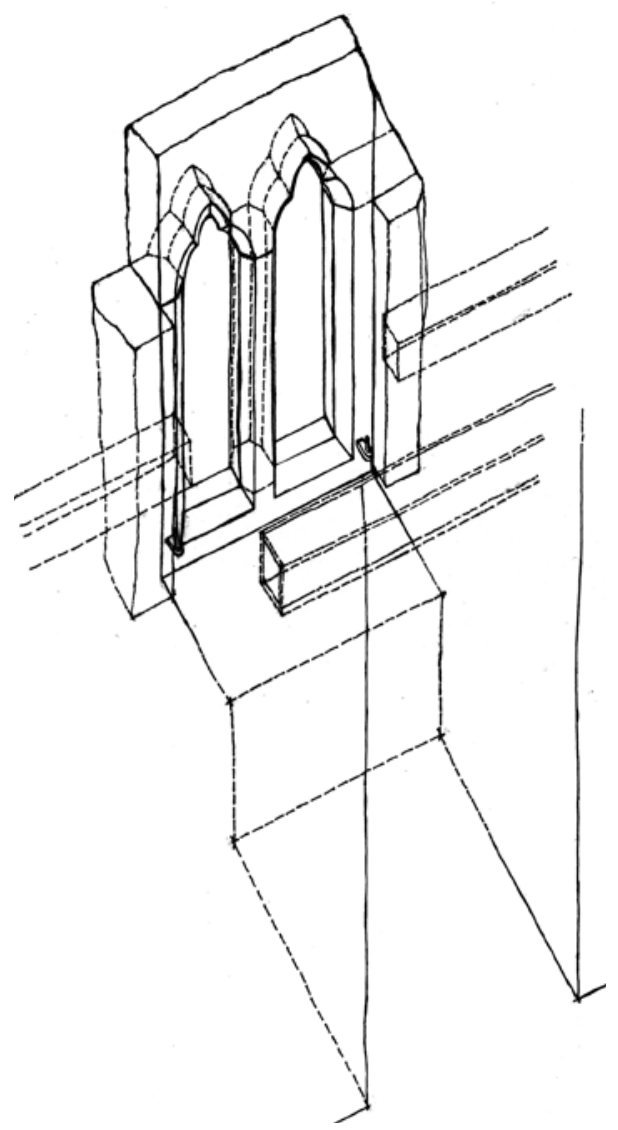

Obr. 7. Šaumburk, k. ú. Rajnochovice, okr. Kroměříž. Pokus o rekonstrukci původního stavu okenního záklenku, ukázka vědeckého využití dokumentované situace; pohled z interiéru - od severovýchodu (Štětina 2008, převzato: Štětina-Vrla 2008, 107). Abb. 7. Schaumburg, Katastergebiet Rajnochovice, Bezirk Kroměříž. Rekonstruktionsversuch des ursprünglichen Zustandes einer Fensternische, Probe einer wissenschaftlichen Nutzung der dokumentierten Situation; Blick aus dem Innern - von Nordosten (Štětina 2008, entnommen aus: Štětina-Vrla 2008, 107). (obr. 6/B; srov. Vrla-Hodaňová 2008, 76-80; další poznatky o hradě viz Janiš-Schenk-Vrla 2013).

Výsledný stav úpravy nenarušuje prostředí památky, umožňuje účinnou ochranu cenných detailů i jejich, alespoň částečnou prezentaci.

Zubříč (Nový Šaumburk, k. ú. Podhradní Lhota, okr. Kroměříž)

Zříceniny tohoto hradu nalezneme na temeni nižší ostrožny nacházející se hluboko pod výše zmíněným hradem Šaumburkem. Hrad vznikl někdy v první polovině 14 . století jako náhrada zpustlého hradu horního, od kterého převzal i jeho jméno (Zubříč je novodobý název zrríceniny). Zánik tohoto hradu je spojován $\mathrm{s}$ válečnými událostmi po polovině 15. století. Zř́ícenina je dochována $\mathrm{v}$ podobě mohutných terénních útvarů jádra a předhradí a velmi dobře dochovaných okružních valů a př́kopů. Zbytky zdiva, dlouhodobě obnažené amatérskými výkopy, jsou koncentrovány v areálu hradního jádra (Kohoutek 1995, 104107; Plaček 2001, 450, 451; Kolbinger 2002, 114-123).

Hradní jádro a okolní prríkop s valem byly dlouhodobě odlesněny a tyto partie postupně zarostly téměř neprostupným houštím křovin a kopřiv. Neudržovaný areál rovněž posloužil jako smetiště pro obyvatele nedaleké chatové osady. Stav zrrícenin byl tristní; křoviny i nálety rozrušovaly zdivo (obr. 8/A), zanedbaný a téměř nepř́istupný areál nijak neodpovídal významu památky a její patřičné prezentaci. 

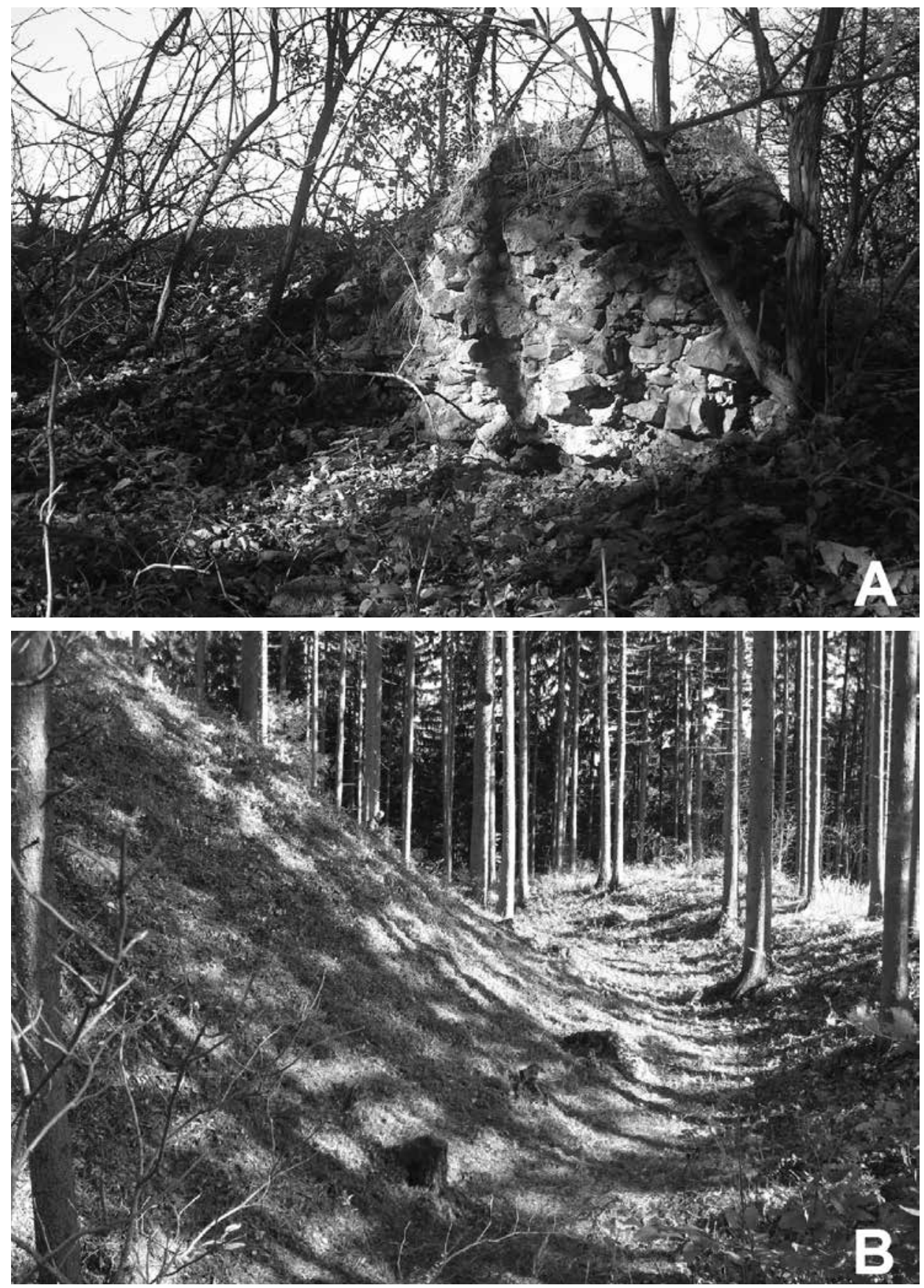

Obr. 8. Nový Šaumburk, k. ú. Podhradní Lhota, okr. Kroměříž. A - detail zdiva, dochovaný v jižní části jádra. Ze snímku je patrno, že zbytky zdiva jsou poškozovány divoce rostoucími nálety (Vrla 2007). B - jižní svah hradního jádra (vlevo) a přilehlý úsek příkopu s valem, stav po vyčištění areálu od náletové zeleně (Vrla 2008).

Abb. 8. Neu Schaumburg, Katastergebiet Podhradní Lhota, Bezirk Kroměříž. A - Detail des im südlichen Teil des Kernareals erhalten gebliebenen Mauerwerks. Aus der Aufnahme ist zu ersehen, dass die Mauerwerksreste durch wildwachsenden Flugbewuchs beschädigt sind (Vrla 2007). B - südlicher Hügel der Kernburg (links) und daran angrenzender Grabenabschnitt mit Wall, Zustand nach Beseitigung des Flugbewuchses (Vrla 2008). 
I zde vypracoval NPÚ $\mathrm{v}$ roce 2008 podklady $\mathrm{k}$ záměru úprav směřujících ke stabilizaci zrríceniny (Vrla-Štětina-Janál 2008). V témže roce došlo za pomoci obce Podhradní Lhota k vyčištění zanedbaného areálu. Díky tomuto zásahu byly odstraněny křoviny i stromy poškozující zdivo. Hradní jádro i přilehlé valové opevnění bylo zbaveno neprostupného porostu a bylo jej možno opět vnímat v celé jeho mohutnosti a kráse (obr. 8/B). I když k následným konzervačním pracím doposud nedošlo, areál hradu je od té doby každoročně čištěn a tak i důstojně prezentován návštěvníkům.

Zuvačov (k. ú. Komňa, okr. Uherské Hradiště)

Pozůstatky tohoto hradu nalezneme na výrazné ostrožně vyrůstající z plochého hřebene Bílých Karpat, který probíhá od Mikulčina vrchu (799 m n.m.) až k městu Bojkovice. Archeo-
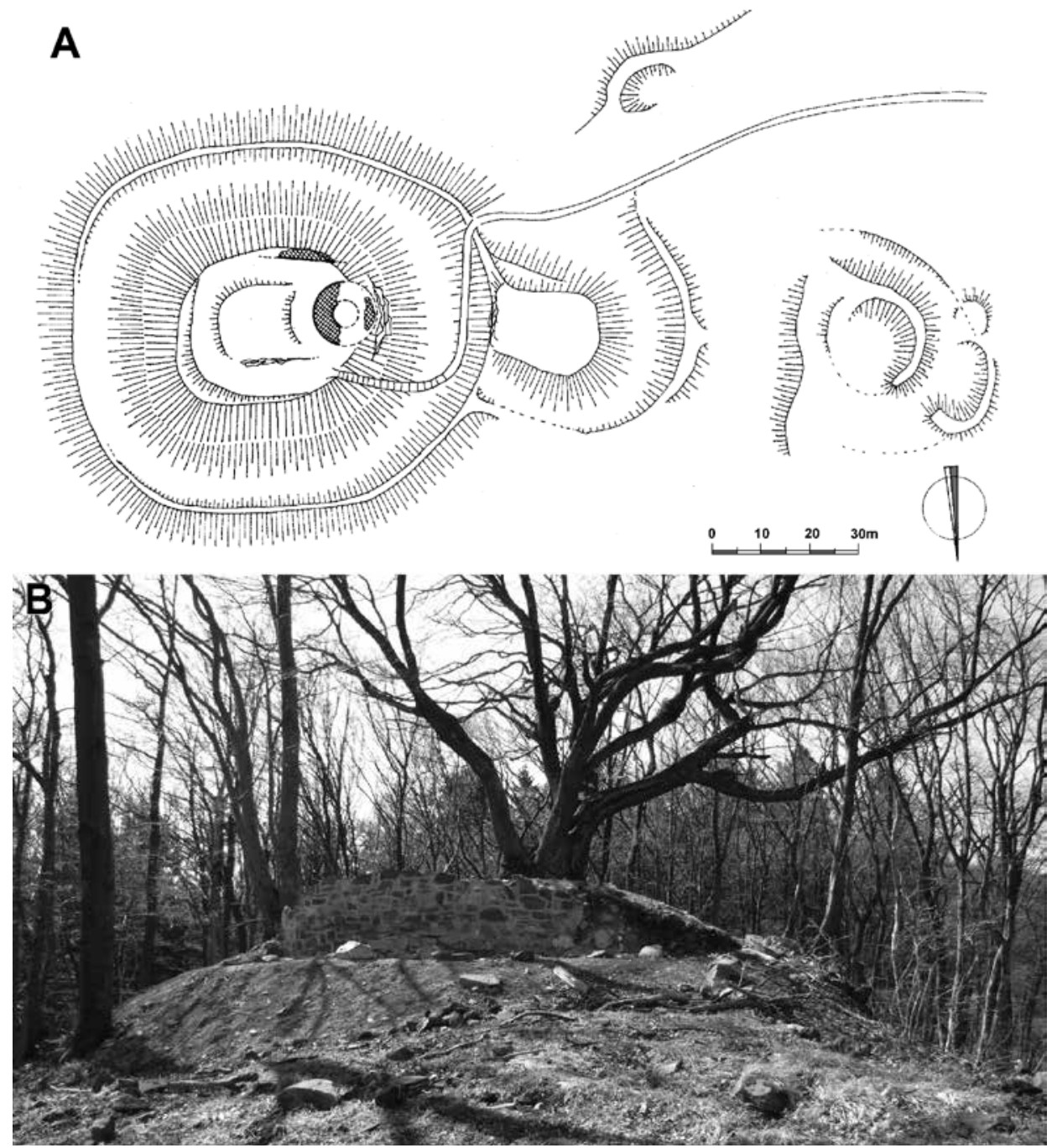

Obr. 9. Zuvačov, k. ú. Komňa, okr. Uherské Hradiště. A - půdorys areálu zříceniny hradu s vyznačením skutečných rozměrů kruhové věže (Vrla 2010). B - pohled na zakonzervovanou zř́iceninu kruhové věže od východu (Vrla 2010).

Abb. 9. Zuvačov, Katastergebiet Komňa, Bezirk Uherské Hradiště. A - Grundriss des Areals der Burgruine mit Kennzeichnung der tatsächlichen Abmessungen des Rundturms (Vrla 2010). B - Blick auf die konservierte Ruine des Rundturms von Osten (Vrla 2010). 
logický průzkum prokázal výstavbu hradu již v období kolem poloviny 13. století, jeho zánik pak nastal při polovině století patnáctého. Jsou zde dochovány mohutné terénní útvary hradního jádra s předhradím obklopené valy a př́k kopy, v předpolí je možno nalézt pozůstatky externího opevnění. V hradním jádru dnes vystupují nad povrch zbytky okrouhlé věže (obr. 9; Kohoutek 1995, 43-47; Plaček 2001, 729-730).

Právě tato věž byla cílem řady amatérských výkopů, které obnažily část jejího zdiva. Na lících věže byly dochovány zbytky omítek, které však záhy zanikly; postupně se začalo velmi rychle rozpadat i nechráněné zdivo a hrozil úplný zánik jeho nadzemní partie.

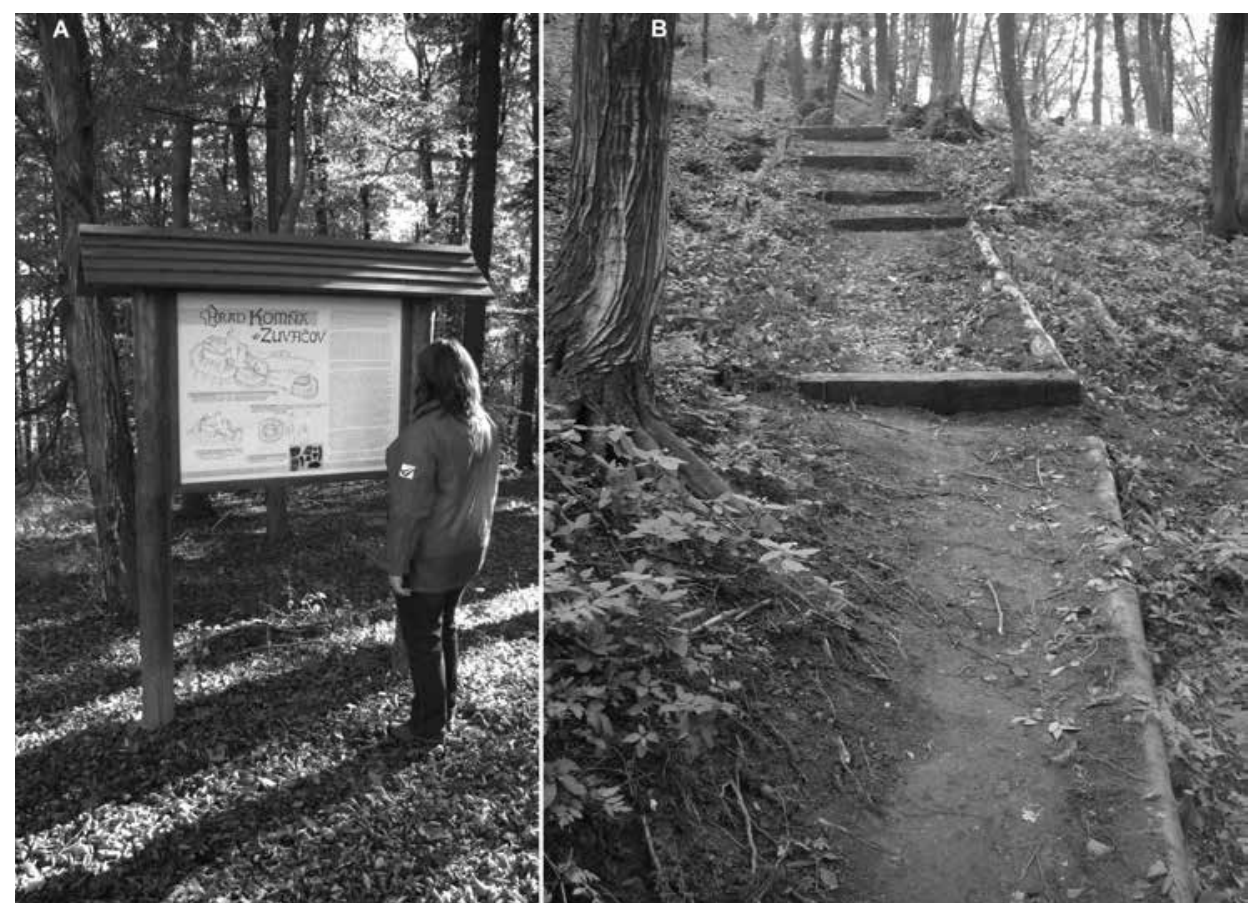

Obr. 10. Zuvačov, k. ú. Komňa, okr. Uherské Hradiště. A - tabule informačního systému situovaná západně, v předpolí zř́iceniny hradu (Vrla 2014). B - terénní schodiště, vybudované na některých úsecích přístupové trasy; jihozápadní svah okružního valu, pohled od západu (Vrla 2014).

Abb. 10. Zuvačov, Katastergebiet Komňa, Bezirk Uherské Hradiště. A - westlich im Vorfeld der Burgruine angebrachte Schautafel des Informationssystems (Vrla 2014). B - an einigen Abschnitten der Zugangstrasse angelegte Geländetreppe, Südwesthang des Ringwalls, Blick von Westen (Vrla 2014).

Nežádoucí situaci ani zde nebylo možno řešit opětovným zasypáním zdiva. Iv tomto př́ípadě byla tedy zvolena ochranná nadezdívka, která by spolehlivě uchránila originální zdivo. V roce 2009 byla NPÚ zorganizována akce spočívající ve vyčištění a dokumentaci zdiva a v následném vybudování nadezdívky chránící obnaženou část zdiva věže (obr. 9/B). Na hradě Zuvačově však došlo i na další potřebné úpravy. Bylo nutno zajistit stabilizaci přístupové trasy - množství prošlapávaných stezek poškozovalo cenné archeologické situace i zdivo, pohyb po nich byl navíc pro návštěvníky poměrně nebezpečný. Z tohoto důvodu byla vytipována optimální trasa, jejíž náročnější úseky byly vybaveny jednoduchými terénními schodišti (obr. 10/B). V předpolí zř́iceniny byla instalována informační tabule, která prostor zříceniny nijak neznehodnocuje a poskytuje návštěvníkovi solidní aktuální informace o hradě (obr. 10/A). ${ }^{1}$ Kromě prací průzkumných a dokumentačních a odborného dohledu byly ostatní práce kapacitně i finančně zajištěny ze strany obce Komňa.

1 Zde je nutno uvést, že kvalitní, informační tabule s aktuálními údaji byla instalována i v předpolí téměř zapomenuté zříceniny hradu Šarova (k. ú. Březolupy, okr. Uherské Hradiště). 

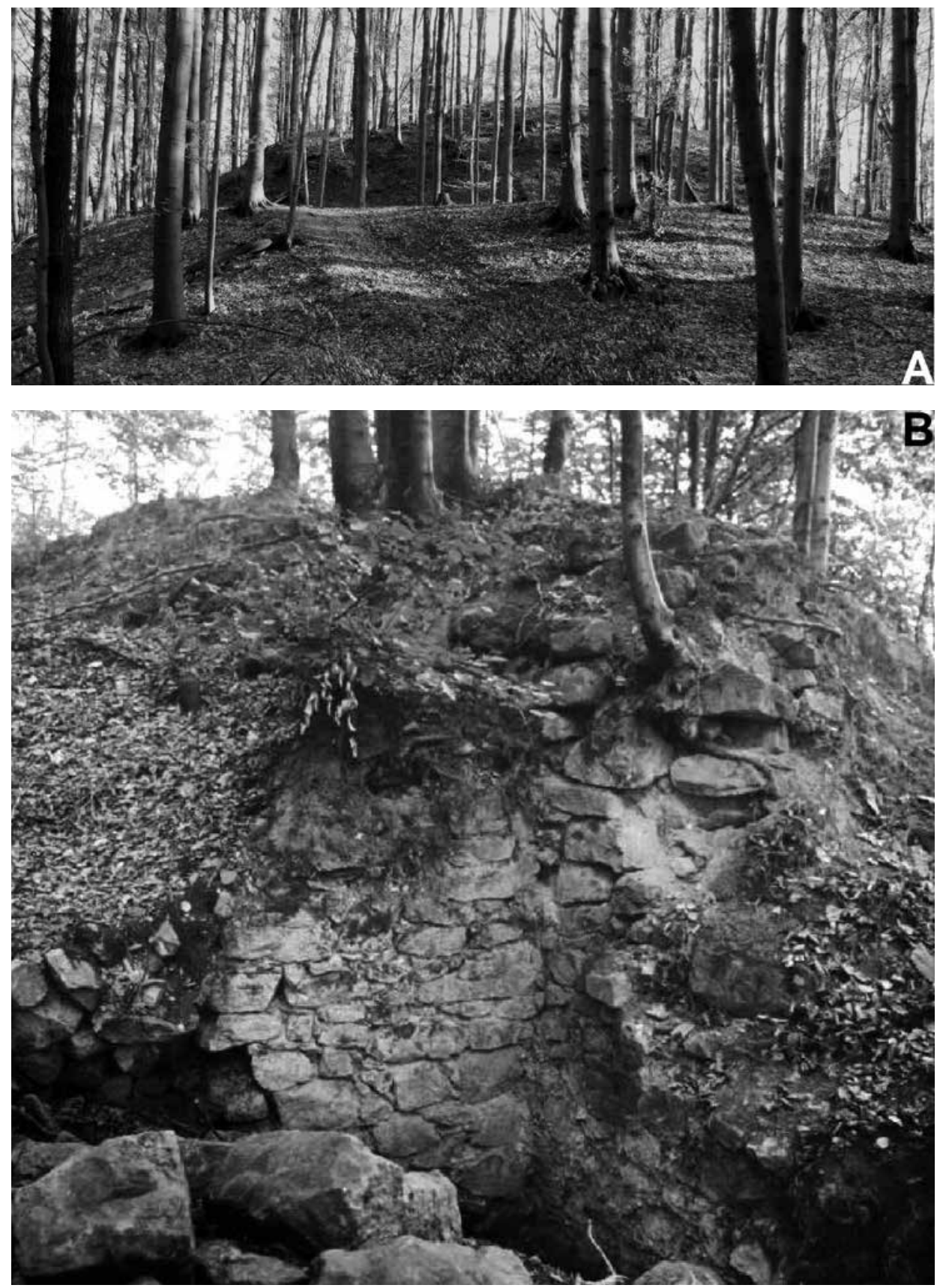

Obr. 11. Starý Světlov, k. ú. Podhradí u Luhačovic, okr. Zlín. A - celkový pohled na mohutné terénní útvary hradního jádra od severovýchodu (2012). B - detail koutu jedné z místností v suterénu hradního paláce, fotografie z první poloviny 20 . století; tato část památky dnes již neexistuje (fotoarchiv NPÚ).

Abb. 11. Alt Swietlau, Katastergebiet Podhradí bei Luhačovice, Bezirk Zlín. A - Gesamtblick auf die mächtigen Geländegebilde der Kernburg von Nordosten (2012). B - Detail einer Raumecke im Souterrain des Burgpalas, Foto aus der ersten Hälfte des 20. Jhdt.; dieser Teil des Denkmals existiert heute nicht mehr (Fotoarchiv des Nationalinstituts für Denkmalpflege). 
Starý Světlov (k. ú. Podhradí, okr. Zlín)

Poměrně vysoko položená zrrícenina hradu zaujímá skalnaté návrší tvořící součást hřebene Vizovických vrchů míríícího od dominantní hory Komonec (672 m n.m.) západním směrem. Hrad byl založen zřejmě v první polovině 14. století jako významné sídlo jedné z rodových větví Šternberků, v 15. století se stal důležitým vojenským a strategickým centrem. Na počátku 16. století je připomínán jako pustý. Do dnešního dne se z rozsáhlého hradu dochovaly impozantní terénní útvary (obr. 11/A) a pozůstatky zděných konstrukcí, soustředěné v prostoru hradního jádra.

Jak bylo možno zjistit ze shromážděné historické dokumentace, nadzemní partie zdiva hradu podlehly poměrně rychlé zkáze, některé z nich, zachycené ještě na nepř́iliš starých fotografí́ch, dnes již neexistují (obr. 11/B). Podobně jako u Zuvačova i zde je terén dlouhodobě narušován přístupovými stezkami, jejichž prošlapávání způsobuje závažná poškození (ničení archeologických situací i obnažovaných partií zdiva apod.).

V roce 2012 zpracoval NPÚ na žádost obce Podhradí u Luhačovic záměr opravy památky (Vrla 2012). Ve srovnání s ostatními zde uvedenými akcemi byl potřebný rozsah prací na Starém Světlově podstatně větší. Bylo to dáno především stupněm narušení dlouhých úseků hradeb a zdiva paláce. Zmíněný záměr byl následně vtělen do projektu, na jehož realizaci obec získala dotaci z Programu rozvoje venkova. Vlastní realizace započala v roce 2013, opět průzkumnými pracemi zajišt'ovanými NPÚ a archeology (Z. Schenk a J. Mikulík, Muzeum J. A. Komenského v Přerově). Součástí těchto prací bylo i pokácení vybraných stromů rostoucích přímo ze zdiva či zdivo výrazně poškozujících. Vzápětí pak započaly práce stavební, jejichž cílem byla citlivá konzervace ohrožených líců zdiva a následné vyzdění ochranné nadezdívky. Stejně jako u jiných lokalit bylo dbáno o to, aby výraz této nadezdívky nepoškodil přírodně-architektonické prostředí památky (obr. 12/B). V některých místech, kde byly lícové partie poškozeny do velké hloubky pod povrchem, byly pohledové lícové partie provedeny z kamenného zdiva skládaného nasucho (obr. 12/A). Na obtížně schůdných místech přístupové trasy byla zřízena jednoduchá terénní schodiště. V rozsáhlém areálu zříceniny byly následně instalovány prvky informačního systému sestávajícího ze tř́i informačních tabulí situovaných u př́stupových cest a v areálu předhradí a dále souboru drobných pultů, na kterých jsou vyobrazeny vizuální rekonstrukce možného vzhledu vybraných partií hradu v době jeho existence (obr. 13). Na tyto práce by měla v nejbližší době navázat konzervace zdiva paláce, čímž by byl účel akce naplněn v celém rozsahu (Vrla 2013).

\section{Závěr}

Záchranné práce na řadě zmíněných lokalit přinesly rovněž pozoruhodné poznatky rozšiřující významně naše znalosti o stavební podobě a stavebním vývoji zkoumaných objektů. Vzhledem k rozsahu předkládané stati zde zmíníme jenom ty nejzajímavější (o archeologických nálezech a historických souvislostech objevů bude referováno jinde): Na hradě Křídlo se podařilo identifikovat pětibokou věž zapojenou do hradeb předhradí a př́i průzkumu zmíněné vstupní věže byly nalezeny pozůstatky konstrukcí souvisejících s použitím kolébkového padacího mostu. Opevnění křídelského předhradí, jehož výstavba proběhla někdy na přelomu 14. a 15. století, můžeme na základě nových zjištění zařadit mezi velmi kvalitní stavební realizace této doby spojené s významným rodem pánů z Cimburka (Vrla 2006; 2009). V rámci konzervace kruhové věže na Zuvačově se konečně podařilo zjistit její rozměry. Vnějším průměrem 12,5 m se řadí k největším stavbám svého druhu v českých zemích (Janiš-Vrla 2010; Vrla 2010). U Starého Světlova pak bylo možno zkoumat pozůstatky doposud neznámé mohutné brány, rovněž vybavené kolébkovým padacím mostem, a rozpoznat dvě stavební fáze rozměrného paláce. ${ }^{2}$

2 Konkrétní poznatky o stavebním vývoji hradu Starého Světlova získané v rámci záchranných prací v roce 2013 budou publikovány později $\mathrm{v}$ časopise Archaeologia historica. 

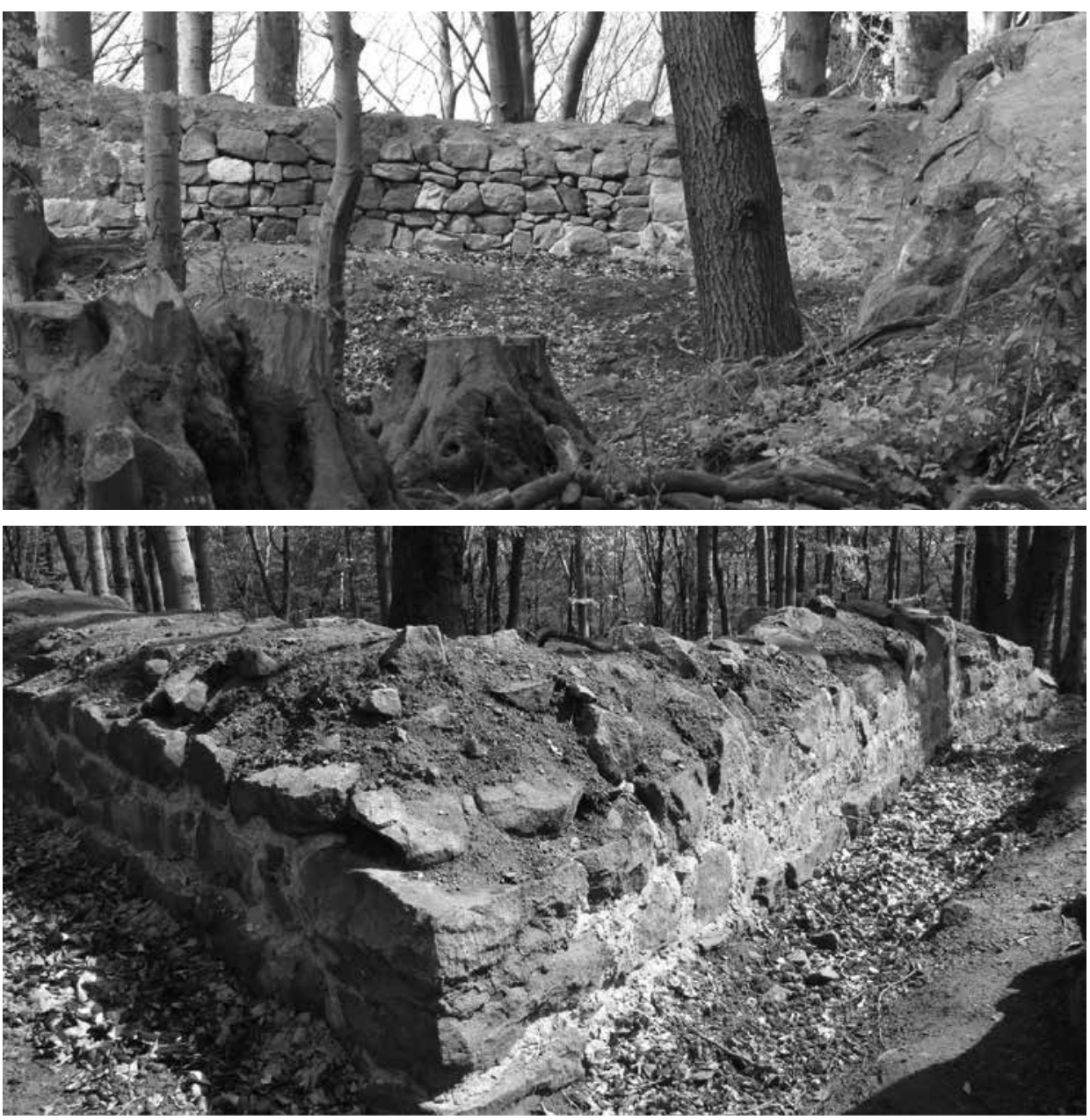

Obr. 12. Starý Světlov, k. ú. Podhradí u Luhačovic, okr. Zlín. Ukázky zakonzervovaného zdiva, opatřeného ochrannou nadezdívkou. A - severozápadní úsek hlavní hradby jádra, pohled od východu, uprostřed partie líce, kladená nasucho (Vrla 2014). B - západní nároží zřícenin paláce, pohled od západu (Vrla 2014).

Abb. 12. Alt Swietlau, Katastergebiet Podhradí bei Luhačovice, Bezirk Zlín. Proben des mit einer Schutzübermauerung versehenen konservierten Mauerwerks. A - nordöstlicher Abschnitt der Hauptwehrmauer des Kernareals, Blick von Osten, in der Mitte Vorderflucht einer Trockenmauerwerkspartie (Vrla 2014). B - Westecke der Palasruinen, Blick von Westen (Vrla 2014).

Zásadní význam provedených akcí však lze spatřovat především v oblasti praktické památkové péče o torzální architekturu, jejímž obsahem je účinná ochrana původních zděných konstrukcí, modelace terénu a kvalitního prostředí památek, jejich důstojná prezentace a zpř́ístupnění informace o jejich hodnotách veřejnosti.

V rámci výše uvedených akcí došlo k obnovení vandalsky poškozené historické modelace povrchu terénu, která bývá nositelkou významných vizuálních informací o existenci zřícených staveb (Hradištěk, Hrádek). Ohrožená a zanikající stř̌edověká zdiva byla opatřena ochrannými nadezdívkami tvořícími vlastně „obětovanou“ vrstvu. Ta je schopna dlouhodobě plnit funkci jakéhosi ochranného štítu vzdorujícího atakům povětrnostních výkyvů i negativním dopadům působení lidského faktoru (Křídlo, Zuvačov, Starý Světlov). Došlo k vymezení a zajištění bezpečných přístupových cest, které navíc zamezí poškozování archeologických situací (Křídlo, Zuvačov, Starý Světlov). Na některých lokalitách se již podařilo zřídit moderní informační systémy, jejichž podoba a umístění nekolidují s výrazovými hodnotami vlastní památky (Zuvačov, 


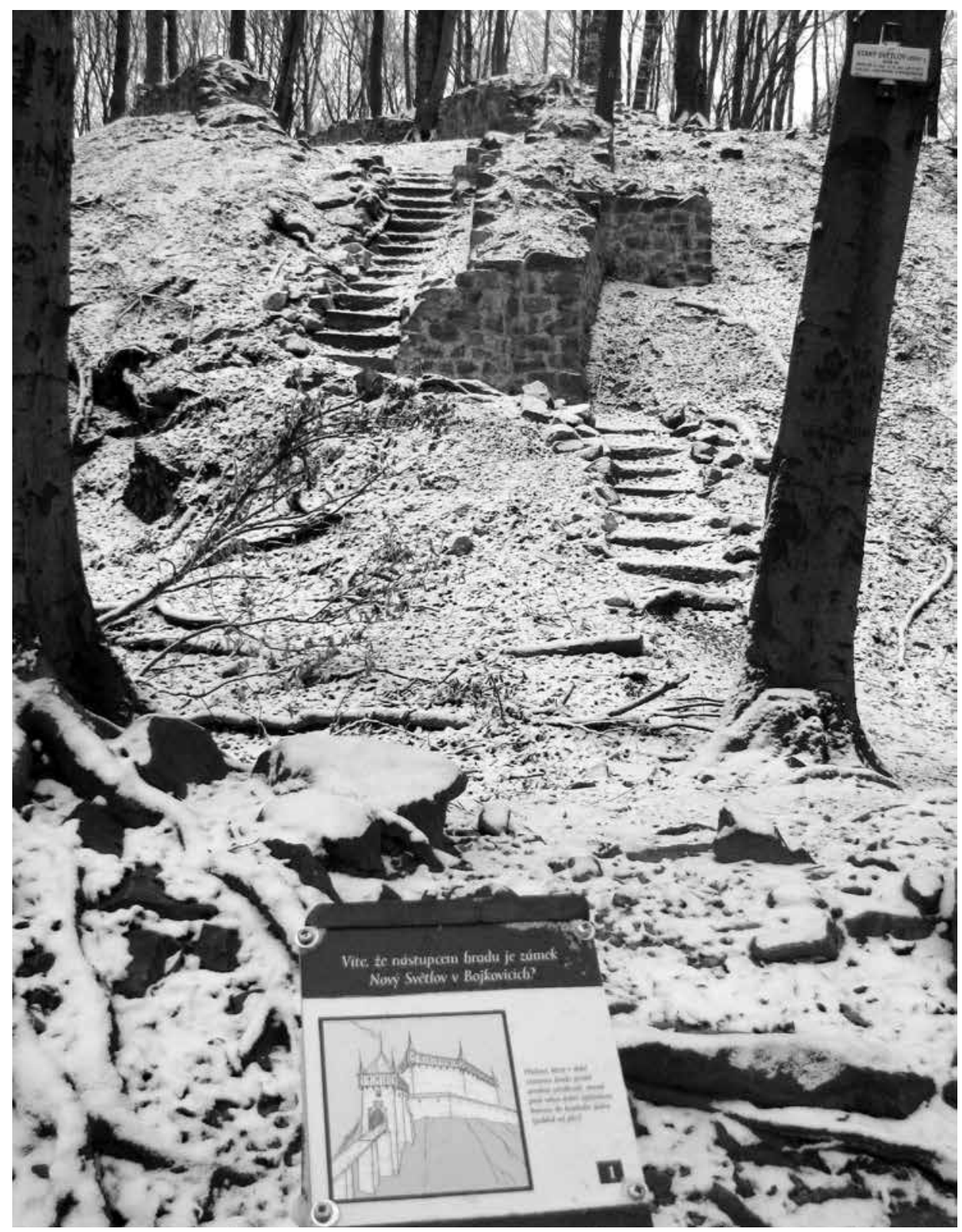

Obr. 13. Starý Světlov, k. ú. Podhradí u Luhačovic, okr. Zlín. Konzervované torzo brány jádra, pohled od jihozápadu; v popředí informační pult s pokusem o pohledovou rekonstrukci podoby této partie hradu v době jeho existence (Vrla 2013).

Abb. 13. Alt Swietlau, Katastergebiet Podhradí bei Luhačovice, Bezirk Zlín. Konservierter Torso des Kernburgtors, Blick von Südwesten; im Vordergrund Schaupult mit hypothetisch rekonstruiertem ehemaligem Aussehen dieser Partie der Burg (Vrla 2013).

Starý Světlov, Šarov). V souvislosti s touto problematikou je užitečné zmínit fakt, že po instalaci drobných obrázkových panelů na Starém Světlově (obr. 13) došlo k výraznému poklesu drobného „běžného“ poškozování lokality (kupř̀. odpadky, ohniště). Tato zařízení umožňují, aby si i nepoučený návštěvník uvědomil, že se nachází v místech někdejší významné a mohutné stavby, což může kladně ovlivnit jeho vztah $\mathrm{k}$ danému místu. Kromě těchto aktivit byla v souvislosti s chystanými či probíhajícími pracemi pořádána řada přednášek pro veřejnost, a to přímo na 
lokalitách, v obcích ležících v jejich blízkosti, ale i v kulturních institucích krajského či bývalých okresních měst.

Jak můžeme soudit dnes, s patnáctiletým odstupem od provedení první akce, praktická péče o takovéto kulturní památky je možná. Uvedené lokality, na kterých proběhly zmíněné zásahy, lze označit $\mathrm{z}$ hlediska památkové péče za stabilizované. K jejich údržbě (ta nyní spočívá především v úklidu a sledování stavu) v podstatě není potřeba dlouhodobě žádných prostředků. Co je velmi důležité, praktickou péči o tyto památky většinou převzali místní lidé. Základy této přirozené aktivity, která je schopna dlouhodobě a účinně památku ochránit, spočívá $\mathrm{v}$ dobré informovanosti o hodnotách i potřebách lokality, kterou zde památková péče dokázala zprostředkovat.

Kladem provedených akcí je bezesporu i další významný fakt. Uvedené práce byly zaměřeny na záchranu „drobných“ pozůstatků významných středověkých architektur, většinou ukrytých v hlubokých lesích. Jejich společným rysem je i to, že provedené úpravy neměly za cíl zvýšení atraktivity, a tedy ani nežádoucí oživení těchto lokalit. Výsledkem práce měla být prostá a účinná konzervace ohrožených částí památek, ne jejich vytržení ze staletími utvářeného př́rodního prostředí plného klidu a lesního ticha.

Tato studie byla zpracována za podpory institucionálního úkolu vědy a výzkumu NPÚ č. 21301 - „Vědecký výzkum a aplikace metod operativního zpracování stavebně historických a umělecko historických průzkumů prováděných při obnově kulturních památek a nemovitostí v památkově chráněných územích“.

\section{Literatura}

HEBER, F. A., 2002: České hrady, zámky a tvrze, díl první, západní Čechy. Praha.

HRČKA, M.-KOHÚT, V.-MAKÝŠ, O., 2006: Výber vhodných techník a materiálov záchrany zrúcanin. In: Kolektív autorov, Ochrana zrúcanin v kultúrnej krajine, 66-65. Lietava.

JANIŠ, D.-VRLA, R., 2010: Hrad Komňa (Zuvačov) - jeho historie a stavební podoba - Die Burg Komňa (Zuvačov) - ihre Geschichte und Baugestaltung, CB 12, 359-368.

JANIŠ, D.-SCHENK, Z.-VRLA, R., 2013: Nové poznatky ke stavebnímu vývoji hradu Šaumburka v Hostýnských vrších - Zu den baulichen Anfängen der Heilige Dreifaltigkeitskirche in Valašské Meziřričí, AH 38, 435-454.

KOHOUTEK, J., 1995: Hrady jihovýchodní Moravy. Zlín.

- 1995a: Drobná středověká šlechtická sídla na Zlínsku. In: Regiom 95, 29-38. Mikulov.

KOLBINGER, D., 2002: Dávnověké osídlení Hostýnských vrchů II., Nový Šaumburk (nesprávně Zubř́ič), Archeologie Moravy a Slezska 2, 96-164.

KOLEKTIV, 1998: Zříceniny historických staveb a jejich památková ochrana. Příloha ZPP 58. Praha.

KOLEKTÍV, 2006: Ochrana zrúcanin v kultúrnej krajine. Lietava.

ŠTĚTINA, J.-VRLA, R., 2008: Okno ve dvorním průčelí severního paláce hradu Šaumburku - Das Fenster in der Hoffassade des Nordpalastes der Burg Šaumburk. In: Dějiny staveb. Sborník příspěvků z konference Dějiny staveb 2008, 102-108. Plzeň.

VRLA, R., 2004: Stavební úpravy hradu Lukova ve 20. a 21. století (př́spěvek k diskusi o problematice záchrany torzální architektury). In: Památková péče na Moravě 8, 77-78. Brno.

- 2005: Hrad Křídlo, studie záchrany ohrožených částí zříceniny, brána, věž, zdivo hradního jádra. Rukopis uložený v archivu NPÚ ÚOP v Kroměříži.

- 2006: Vstupní věž hradu Křídlo a stř̌edověké padací mosty kolébkové konstrukce - Das Eingangstor der Burg Křídlo und mittelalterliche Fallbrücken der Wippenkonstruktion. In: Dějiny staveb. Sborník příspěvků z konference Dějiny staveb 2006, 94-108. Plzeň.

- 2008: Chránit, či oživit? Několik poznámek k praktické ochraně hradních zřícenin. In: Veřejná archeologie II. Př́íspěvky ke konferenci Archeologie a veřejnost 2005, 107-116. Ústí nad Labem.

- 2009: Předhradí hradu Kř́idlo - Die Vorburg der Burg Křídlo. In: Dějiny staveb. Sborník příspěvků z konference Dějiny staveb 2009, 55-64. Plzeň.

- 2010: Kruhová věž hradu Komňa (Zuvačov), náhled do problematiky památkového průzkumu a následné ochrany hradní zrríceniny. In: Ingredere Hospes III. Sborník Národního památkového ústavu, územního odborného pracoviště v Kroměřiži, 93-97. Kroměříž. 
- 2011: Šest let na Kř́́dle. In: Ingredere Hospes IV. Sborník Národního památkového ústavu, územního odborného pracoviště v Kroměříži, 122-125. Kroměříž.

- 2012: Hrad Starý Světlov - zadání opravy kulturní památky. Rukopis uložený v archivu NPÚ ÚOP v Kroměříži.

- 2013: Hrad Starý Světlov - zadání druhé fáze konzervace zdiva. Rukopis uložený v archivu NPÚ ÚOP v Kroměřízi.

VRLA, R.-HODAŇOVÁ, K., 2008: Památková péče a torzální architektura - poznámky z praxe. In: Ingredere Hospes I. Sborník Národního památkového ústavu, územního odborného pracoviště v Kroměříži, 72-80. Kroměříž.

VRLA, R.-SLUŠTÍKOVÁ, H., 2010-2011: Zříceniny hradů ve Zlínském kraji a památková péče o ně, Acta Musaei Scepusiensis (Slovenské národné múzeum, Spišské múzeum v Levoči), 136-153.

VRLA, R.-ŠTĚTINA, J.-JANÁL, J., 2006: Hrad Šaumburk (k. ú. Podhradní Lhota), záchrana torza okenního otvoru v severním paláci. Rukopis uložený v archivu NPÚ ÚOP v Kroměřǐži.

\section{Zusammenfassung}

\section{Denkmalpflege an torsalen Architekturen im Landkreis Zlín}

Der Landkreis Zlín liegt in Ostmähren. Auf seinem Gebiet können 34 Burgen und ihre Ruinen gefunden werden. Die regionale Fachstelle des Nationalinstituts für Denkmalpflege in Kroměříž widmet sich bereits über einen langen Zeitraum hinweg dem Denkmalschutz von torsalen Architekturen. Anfänge dieser Bemühungen lassen sich dort bereits im 19. Jahrhundert finden (z.B. Burg Cimburk bei Koryčany). Die meisten Bemühungen um die Rettung von Ruinen betreffen vor allem monumentale Objekte wie beispielsweise die Burg Lukov (Luckow). Die dortigen Maßnahmen zur Denkmalerhaltung wurden bei einer Reihe anderer Objekte zum Ausgangspunkt genommen, die methodischen Vorgehensweisen festzulegen (z.B. Vrla 2004).

Zu ernsthaften Beschädigungen kommt es jedoch auch an Ruinen, von denen weniger Mauerwerk erhalten geblieben ist. Gerade diesen Objekten wurde im Landkreis Zlín über einen langen Zeitraum hinweg Beachtung geschenkt. Der Ertragsnutzen dieser Aktivitäten lässt sich wiefolgt zusammenfassen:

An sieben Fundstellen brachten die Rettungsarbeiten völlig neue Erkenntnisse über ihre bauliche Entwicklung. Auf der Burg Kř́dlo konnte ein fünfeckiger Turm identifiziert werden, der in die Wehrmauer der Vorburg eingegliedert worden war. Ferner wurde nachgewiesen, dass sich im Eingangsturm eine Zugbrücke mit Wiegenkonstruktion befand. Die Befestigung der Vorburg von der Wende des 14. und 15. Jahrhunderts zählt zu den qualitativ sehr hochwertigen zeitgenössischen Bauten (Vrla 2006; 2009). Auf der Burg Zuvačov wurden die Maße eines Rundturms aus der Mitte des 13. Jahrhunderts ermittelt. Mit seinem Außendurchmesser von 12,5 m gesellt er sich zu den größten Bauten seiner Art in den Ländern Böhmens (Janiš-Vrla 2010; Vrla 2010). Auf der Burg Šaumburk (Schaumburg) wurde eine Fensternische aus der zweiten Hälfte des 13. Jahrhunderts dokumentiert. Bei der Burg Starý Světlov (Alt Swietlau) konnten dann die Überreste eines bislang unbekannten mächtigen Tors untersucht werden, das ebenfalls mit einer Zugbrücke mit Wiegenkonstruktion versehen war.

Die weitere Bedeutung der durchgeführten Aktivitäten liegt im Bereich der praktischen Denkmalpflege und in einer würdigen Präsentation der Denkmäler. So wurden durch Vandalismus beschädigte historische Modellierungen von Geländeoberflächen wiederhergestellt, die bedeutende Informationen über die abgerissenen Gebäude enthalten (Hradištěk, Hrádek). Bedrohte mittelalterliche Mauerwerke wurden mit einer Schutzübermauerung versehen. (Křídlo, Zuvačov, Starý Světlov). Es wurden sichere Zugangswege befestigt, welche Beschädigungen der archäologischen Situationen verhinderten (Křídlo, Zuvačov, Starý Světlov). In manchen Fällen wurden moderne Informationssysteme installiert, die nicht mit den Aussagewerten der Denkmäler selbst kollidierten (Zuvačov, Starý Světlov, Šarov). Auf der Burg Starý Světlov wurden Schautafeln angebracht, die das mutmaßliche Aussehen des jeweiligen Teils der Burg zeigen 
(Abb. 13). Dadurch wurde das Ausmaß der üblichen Beschädigungen an der Fundstelle gemindert (Müll, Feuerstellen u.ä.). Auch ein unkundiger Besucher wird sich dadurch dessen bewusst, dass er sich an einem Ort befindet, an welchem ein bedeutendes und mächtiges Bauwerk existiert, was seinen Bezug zu diesem Ort beeinflusst. Ferner wurde eine Reihe lokaler Vorträge über den Wert dieser Objekte veranstaltet.

Heute kann festgehalten werden, dass die Ruinen, an denen die erwähnten Arbeiten erfolgten, im Hinblick auf die Denkmalpflege stabilisiert wurden. Wichtig dabei ist, dass ihre Pflege jetzt von der örtlichen Bevölkerung wahrgenommen wird. Diese ist dazu in der Lage, ein Denkmal langfristig und wirksam zu schützen.

Die Arbeiten waren vor allem auf die Rettung von Torsi mittelalterlicher Architekturen ausgerichtet, die in tiefen Wäldern liegen. Die durchgeführten Instandsetzungsarbeiten sollten weder eine übertriebene Steigerung der Attraktivität noch eine unerwünschte Belebung dieser Fundstellen mit sich bringen. Ergebnis der Arbeiten ist eine einfache und wirksame Konservierung der bedrohten Teile der Denkmäler, die sie nicht aus ihrer über Jahrhunderte hinweg gebildeten, natürlichen, von der Ruhe und Stille des Waldes geprägten Umgebung herausreißt.

Die vorliegende Studie wurde ausgearbeitet unter Förderung der institutionellen Aufgabe von Wissenschaft und Forschung des Nationalinstituts für Denkmalpflege Nr. 21301 - „Wissenschaftliche Forschung und Anwendung operativer Bearbeitungsmethoden von bei der Restaurierung von Kulturdenkmälern und Immobilien in Denkmalschutzgebieten durchgeführten, bauhistorischen und kunsthistorischen Untersuchungen“".

Radim Vrla, Národní památkový ústav, územní odborné pracoviště v Kroměřiži, Sněmovní náměstí 1, 76701 Kroměříž,vrla@kromeriz.npu.cz 
